International Journal of

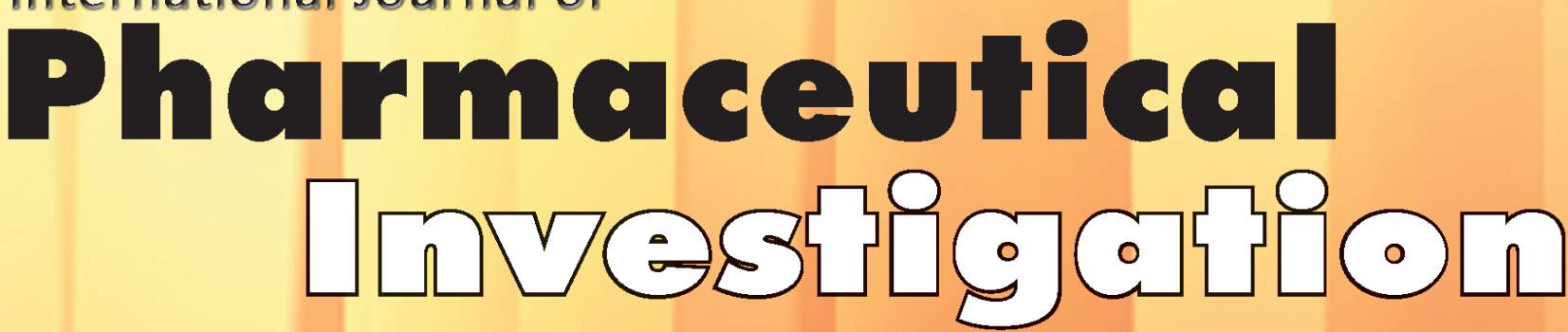

A publication of Phcog.Net

Vol 10 | Issue 2 | Apr-Jun 2020

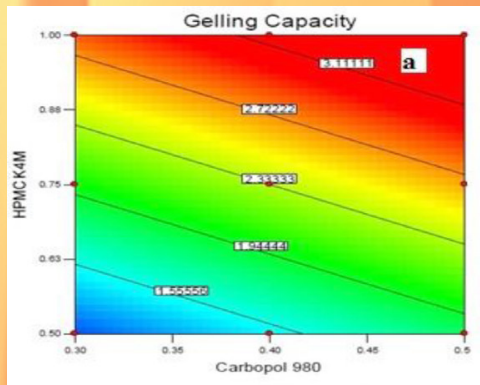

Gel Strength

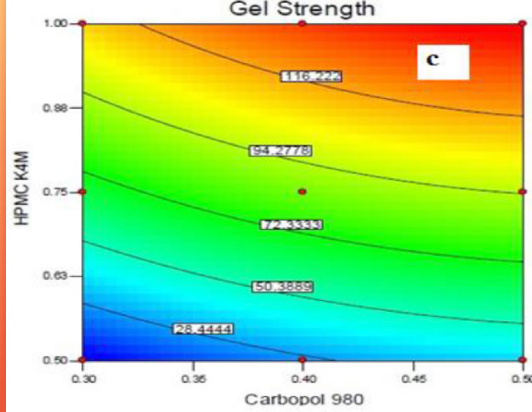

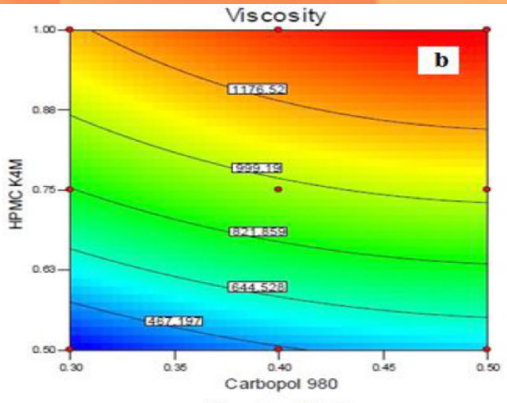

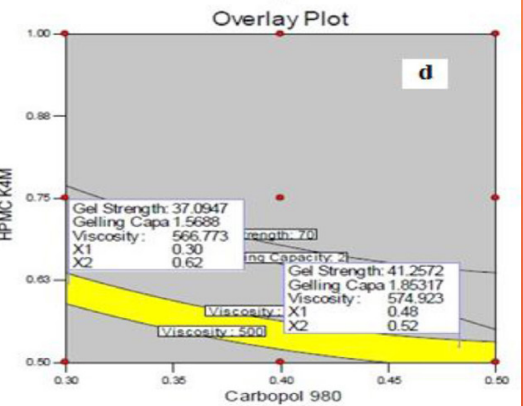

Figure showing Contour plots for a) Gelling capacity b) Viscosity c) Gel strength d) Overlay plot.

Mahajan A, Patel P, Kareliya N. Ophthalmic pH Triggered in situ Gelling System of Tobramycin: Formulation and Optimization using Factorial Design. Int. J. Pharm. Investigation. 2020;10(2):151-4.

The journal is registered with the following abstracting partners:

Baidu Scholar, CNKI (China National Knowledge Infrastructure), EBSCO Publishing's

Electronic Databases, Ex Libris - Primo Central, Google Scholar, Hinari, Infotrieve,

National Science Library, ProQuest, TdNet, Wanfang Data

The journal is indexed with, or included in, the following:

Emerging Sources Citation Index, Index Copernicus, Web of Science 


\title{
Phytochemical Screening and Liquid Chromatography-Mass Spectrometry Studies of Ethyl Acetate Extract of Origanum vulgare
}

\author{
Reyaz Hassan Mir, Mubashir Hussain Masoodi* \\ Pharmaceutical Chemistry Division, Department of Pharmaceutical Sciences, University of Kashmir, Hazratbal, Srinagar, Jammu and Kashmir, INDIA.
}

\begin{abstract}
Background: Origanum vulgare is a perennial shrub that grows in the mountains of the Mediterranean and Euro/lran-Siberian regions. Objectives: This study was conducted to identify the major constituents of the ethanolic extract of Origanum vulgare by Liquid chromatography/mass spectroscopy analysis. Methods: The leaves of Origanum vulgare were powdered and the powdered sample of plant material was then subjected to extraction by maceration process for $72 \mathrm{~h}$. The extract obtained was filtered through Whatman filter paper and concentrated under reduced pressure using a rotary vacuum evaporator. Results: The extract contained monoterpene hydrocarbons and phenolic compounds, the major ones being Chlorogenic acid, p-cymene and phytol. Conclusion: Taken together, these results reinforce the importance of this millennial species and open new perspec-
\end{abstract}

tives for the research and design of new herbal medicines, obtained from indigenous vegetal material.

Key words: Origanum vulgare, Polyphenols, Phytochemicals.

Correspondence

Dr. Mubashir Hussain Masoodi,

Pharmaceutical Chemistry Division, Department of Pharmaceutical Sciences, University of Kashmir, Hazratbal, Srinagar-190006, Jammu and Kashmir, INDIA.

Phone: +91 7006320884

Email: mubashir@kashmiruniversity.ac.in;

ORCID: http://orcid.org/0000-0002-3729-5303

DOI: 10.5530/ijpi.2020.2.24

\section{INTRODUCTION}

Medicinal herbs have been the source of a wide range of biologically active compounds for many centuries and they have been used extensively as crude plant extracts or as pure components for treating a variety of disease conditions. Unlike allopathic drugs which are single active compounds that can specifically target one pathway, herbal remedies work in a way that depends on a synergistic approach. A plant contains a multitude of molecules that synergistically act on targeted elements of the cellular complex pathway. ${ }^{1}$ When compared to synthetic ones most natural remedies generally have fewer side effects and toxicity. So, nowadays the use of herbal remedies has increased when compared to allopathic drugs. ${ }^{2}$ In the development of potential therapeutic agents, medicinal plants play an important role. The Himalayas, with a very rich repository of medicinal herbs ${ }^{3}$ may maintain an important position in the production of raw materials either directly for crude drugs or as the bioactive components in the formulation of pharmaceuticals and cosmetics. ${ }^{4}$ Origanum vulgare L. (Lamiaceae), native to the Mediterranean region and western Eurasia, is an aromatic perennial herb, 30-50 cm tall, white- or purple-flowered, with the opposite, lanceolate and toothed leaves ${ }^{5}$ (Figure 1). Origanum vulgare is recognized throughout the world as a flavoring herb. It is also used in traditional medicine for its health effects, mainly against bronchial disorders ${ }^{6,7}$ as digestive and antiseptic, for treating colds, indigestion and stomach upsets. The aerial parts contain a wide array of medicinally active components, including phenolic glycosides, flavonoids, tannins, sterols and high amounts of terpenoids. Their content can vary due to the presence of different chemo-types in the same species, geographical region of origin and harvest time..$^{8-12}$ These and other factors can result in different pharmacological effects. The current study was conducted to identify the major constituents of the ethyl acetate extract of Origanum vulgare by Liquid chromatographymass spectroscopy analysis.

\section{MATERIALS AND METHODS}

The leaves of Origanum vulgare (Figure 1) was procured from the market from Srinagar, Jammu and Kashmir, India. This plant was identified and authenticated by Akhtar H. Malik, Curator Centre for Biodiversity and Taxonomy (CBT) Department of Botany, the University of Kashmir under specimen voucher no. $2710 \mathrm{KASH}$. A sample specimen of collected material was deposited in the herbarium for future references.

\section{Preparation of Extract}

The leaves of Origanum vulgare were powdered and the powdered sample of plant material was then subjected to extraction by maceration process for $72 \mathrm{~h}$. The extract obtained was filtered through Whatman filter paper and concentrated under reduced pressure using a rotary vacuum evaporator. The extract was then dried and transferred into a closed airtight container and stored at $-20^{\circ} \mathrm{C}$ for further use.

\section{Phytochemical screening}

The preliminary phytochemical screening was carried out on the ethyl-acetate fraction of Origanum vulgare to determine the presence of various phytoconstituents as shown in Table $1 .^{13}$

\section{Liquid Chromatography-Mass Spectroscopy (LC-MS)}

The chemical constituents of the ethyl-acetate extract of Origanum vulgare were determined using LC-MS. LC-MS analysis was performed using Mariner Bio spectrometry equipped with a binary pump. The HPLC was interfaced with a Q-TOF mass spectrometer fitted with an ESI source. Full-scan mode from m/z 100 to 1200 was performed with a source temperature of $140^{\circ} \mathrm{C}$. HPLC column Phenomenex $5 \mu \mathrm{C} 8,(150 \times 2 \mathrm{~mm}$ i.d $)$ was used for the analysis. The solvent was methanol with $0.3 \%$ formic acid. Solvents were delivered at a total flow rate of $0.1 \mathrm{~mL} / \mathrm{min}$. The solvent was run by isocratic elution. The MS spectra were acquired in

This is an open access article distributed under the terms of the Creative Commons Attribution-NonCommercial-ShareAlike 4.0 License, which allows others to remix, tweak, and build upon the work non-commercially, as long as the author is credited and the new creations are licensed under the identical terms. 

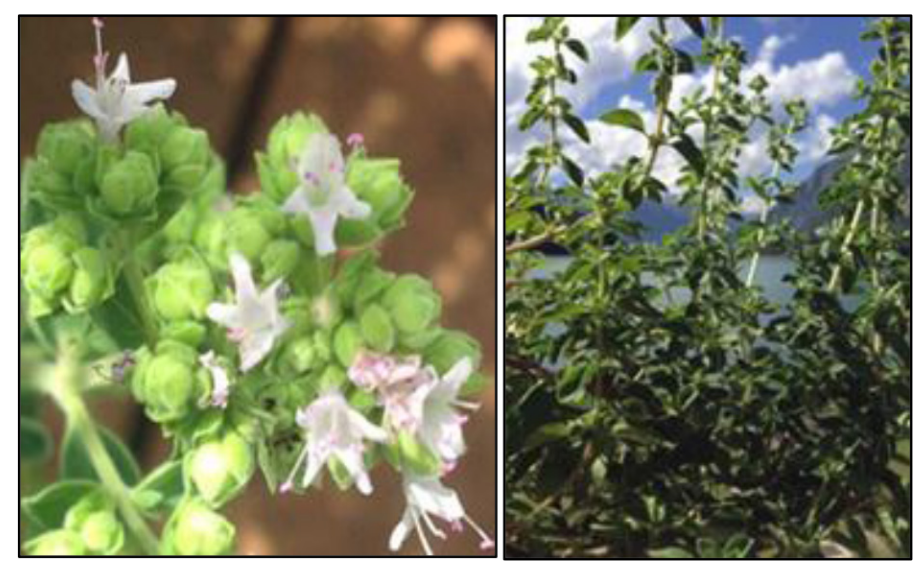

Figure 1: Oreganum vulgare aerial parts.

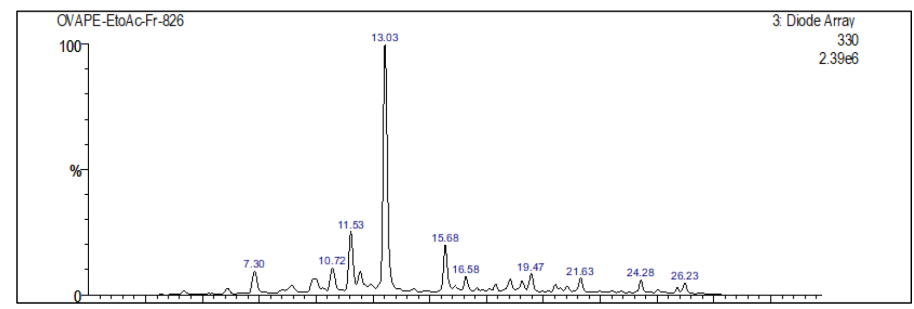

Figure 2: LC-MS chromatogram of an ethyl-acetate extract fraction of Oreganum vulgare.

Table 1: Phytochemical Screening of ethyl-acetate extract of Origanum vulgare.

\begin{tabular}{|c|c|c|c|}
\hline Constituents & Test & Inference & $\begin{array}{l}\text { Ethyl- } \\
\text { acetate }\end{array}$ \\
\hline \multirow[t]{4}{*}{ Carbohydrates } & Molish's test & Violet ring & + \\
\hline & Fehling's test & Brick red ppt & + \\
\hline & Barfoed's test & Brick red ppt & + \\
\hline & Selwinoff's test & Pink color & + \\
\hline \multirow[t]{2}{*}{ Tannins } & $5 \% \mathrm{FeCl}_{3}$ & Yellow color & - \\
\hline & Lead acetate & White ppt & - \\
\hline \multirow[t]{2}{*}{ Saponins } & Foam test & Foaming & - \\
\hline & Froth test & Frothing & - \\
\hline Flavonoids & Shinoda test & Pink color & + \\
\hline Phenolics & $1 \% \mathrm{FeCl} 3$ & Bluish color & + \\
\hline $\begin{array}{l}\text { Anthraquinone } \\
\text { Glycosides }\end{array}$ & Borntrager's test & Pink Color & - \\
\hline Terpenoids & Salkowski's test & $\begin{array}{l}\text { The golden yellow } \\
\text { ring at the junction }\end{array}$ & + \\
\hline Phytosterols & Libermann's test & $\begin{array}{l}\text { Brown ring at the } \\
\text { junction }\end{array}$ & + \\
\hline \multirow[t]{2}{*}{ Alkaloids } & $\begin{array}{l}\text { Dragendroff's } \\
\text { reagent }\end{array}$ & Orange ppt & - \\
\hline & Mayer's reagent & Cream ppt & - \\
\hline \multirow[t]{2}{*}{ Proteins } & Ninhydrin test & Purple color & - \\
\hline & Biuret test & Blue color & - \\
\hline
\end{tabular}

Symbol denoted: $(+)$ sign indicates the presence and (-) sign indicates the absence of Phyto-constituents
Table 2: Important compound identified from the ethyl-acetate extract of Origanum vulgare by LC-MS.

\begin{tabular}{cccccc}
\hline Peak & $\begin{array}{c}\text { Retention } \\
\text { time }\end{array}$ & $\begin{array}{c}\text { Name of the } \\
\text { compound }\end{array}$ & $\begin{array}{c}{\left[\mathrm{M} \mathrm{H}^{+},\right.} \\
\mathrm{m} / \mathbf{z}\end{array}$ & $\begin{array}{c}\text { UV } \\
\text { Detection }\end{array}$ & $\begin{array}{c}\text { MS } \\
\text { Detection }\end{array}$ \\
\hline 1 & 14.23 & Quercetin & 301 & $200,268,336$ & yes \\
2 & 15.65 & p-cymene & 135 & 201,288 & yes \\
3 & 13.3 & 1-hexacosanol & 383 & 201,330 & yes \\
4 & 11.16 & Luteoloin & 287 & 200,308 & yes \\
5 & 10.57 & $\begin{array}{c}\text { Chlorogenic } \\
\text { acid }\end{array}$ & 355 & $225,263,296$ & yes \\
6 & 14.07 & Phytol & 129 & 200,254 & yes \\
\hline
\end{tabular}

the positive ion mode. The temperature of the drying gas $\left(\mathrm{N}_{2}\right)$ was $350^{\circ} \mathrm{C}$ at a glass flow rate of $6 \mathrm{~mL} / \mathrm{min}$ and a nebulizing pressure $\left(\mathrm{N}_{2}\right)$ of $25 \mathrm{psi}$. About $0.5 \mathrm{~g}$ of sample extract was diluted with methanol and filtered with a $0.22 \mu \mathrm{m}$ nylon filter before analysis. A $5 \mu \mathrm{l}$ volume of the ethylacetate extract was injected onto the analytical column for analysis. The mass fragmentations were identified by using the spectrum database for organic compounds in SDBS application. ${ }^{14,15}$

\section{RESULTS}

\section{Phytochemical screening}

The curative properties of medicinal plants are perhaps due to the presence of various secondary metabolites such as alkaloids, flavonoids, glycosides, phenols, saponins, sterols, etc. The extracts of Origanum vulgare have been evaluated for the presences of alkaloids, flavonoids, glycosides, phenols, saponins, sterols and triterpenoids, tannins, quinines, coumarins, resins, anthraquinones, phlobatannin, catechol, acidic compounds, reducing sugars, carbohydrates, proteins and amino acids, phenols and glycosides. Results of preliminary screening of Origanum vulgare extracts are Table 2 .

\section{Liquid Chromatography-Mass Spectroscopy(LC-MS)}

The Liquid Chromatography-Mass Spectroscopy (LC-MS) of an ethylacetate extract fraction of Origanum vulgare shown in (Figure 2) showed a molecular peak (base peak) at m/z 301 (Figure 3) is good agreement with the compound having Chemical Formula: $\mathrm{C}_{15} \mathrm{H}_{10} \mathrm{O}_{7}$ Quercetin (1). The compound showing molecular peak (base peak) at $\mathrm{m} / \mathrm{z} 135$ (Figure 4) is good agreement with compound p-cymene(2)Chemical Formula: $\mathrm{C}_{10} \mathrm{H}_{14}$. The fragmentation has shown a peak at $\mathrm{m} / \mathrm{z} 383$ (Figure 5) and it showed the presence of compound 1-hexacosanol(3)Chemical Formula: $\mathrm{C}_{26} \mathrm{H}_{54} \mathrm{O}$. The mass spectrum showed the molecular peak (base peak) at $\mathrm{m} / \mathrm{z} 287$ (Figure 6) is good agreement with compound empirical formula Luteoloin (4) Chemical Formula: $\mathrm{C}_{15} \mathrm{H}_{10} \mathrm{O}_{6}$. The fragmentation has shown a peak at $\mathrm{m} / \mathrm{z} 355$ (Figure 7) and it showed the presence of Chlorogenic acid (5). The compound showed a molecular peak (base peak) atm/z 129 (Figure 8) is exactly in agreement with the compound Phytol (6) Chemical Formula: $\mathrm{C}_{20} \mathrm{H}_{40} \mathrm{O}$.

\section{DISCUSSION}

Plants have provided a source of inspiration in the drug development as plants derived compounds have made a significant contribution towards human health. Plant-derived Phyto-constituents are to be used for the treatment of diseases as is done in the case of the Unani and Ayurvedic system of medicines. Besides, plants are an important source of potentially useful structures for the development of new chemotherapeutic agents and in identifying the active principle responsible for curing various human diseases. In Present study, the chemical constituents of the 

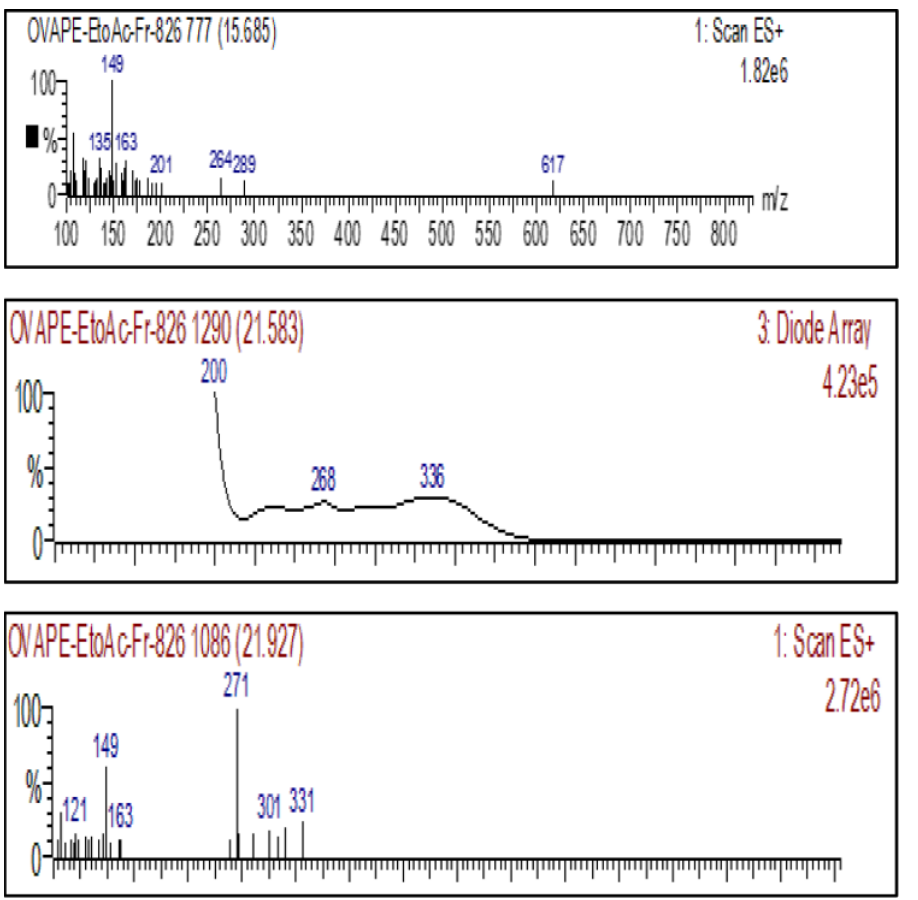

Figure 3: Mass and UV spectrum Quercetinat the retention time 21.92.

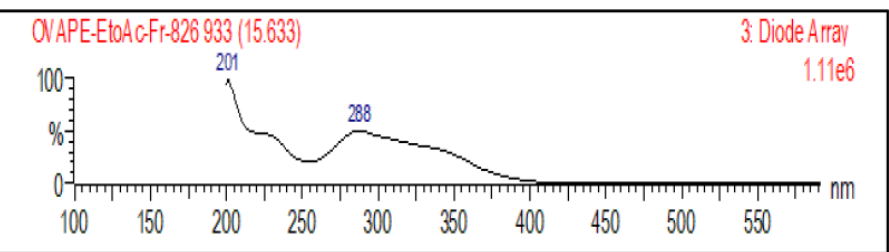

Figure 4: Mass and UV spectrumat the retention time 15.65.
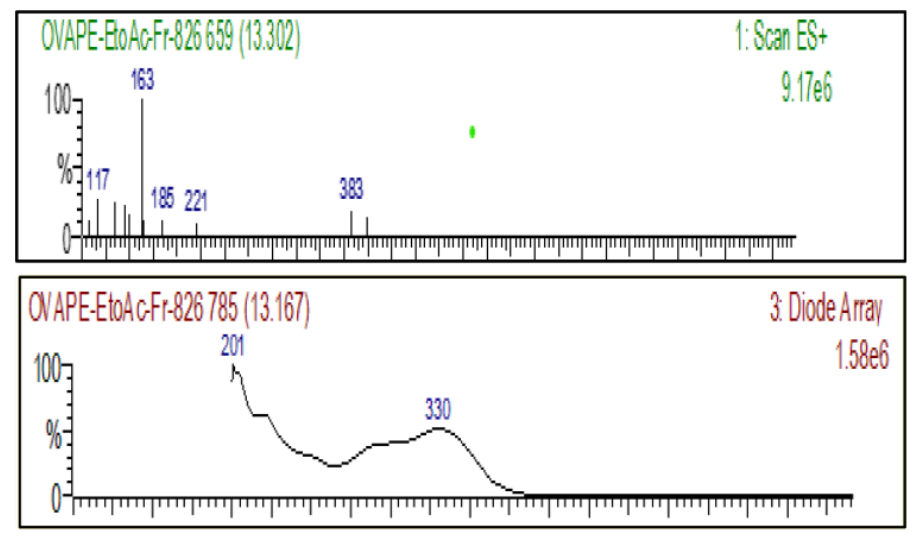

Figure 5: Mass and UV spectrum at the retention time 13.3.

ethyl-acetate extract were determined using LC-MS. LC-MS analysis was performed using Mariner Bio spectrometry equipped with a binary pump and the mass fragmentations were identified by using the spectrum database for organic compounds in SDBS application. A total of six intense peaks were observed in the LC-MS chromatogram of an ethylacetate extract of Origanum vulgare which are further characterized by mass and UV spectrum along with retention time. The compounds

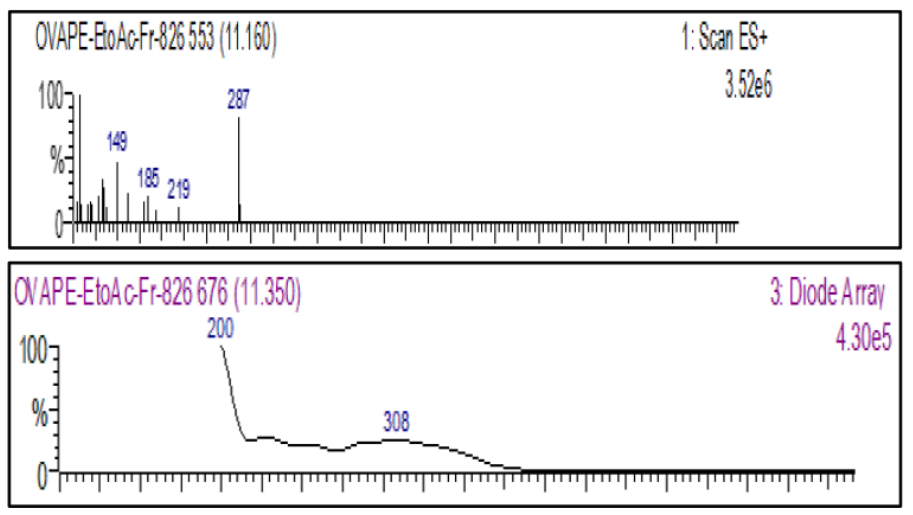

Figure 6: Mass and UV spectrum at the retention time 11.16.

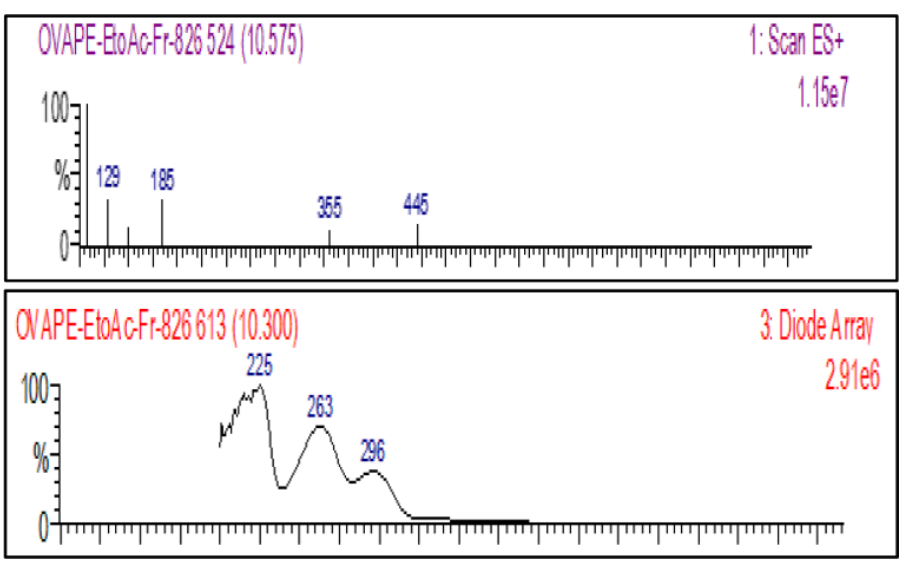

Figure 7: Mass spectrum at the retention time 10.72.
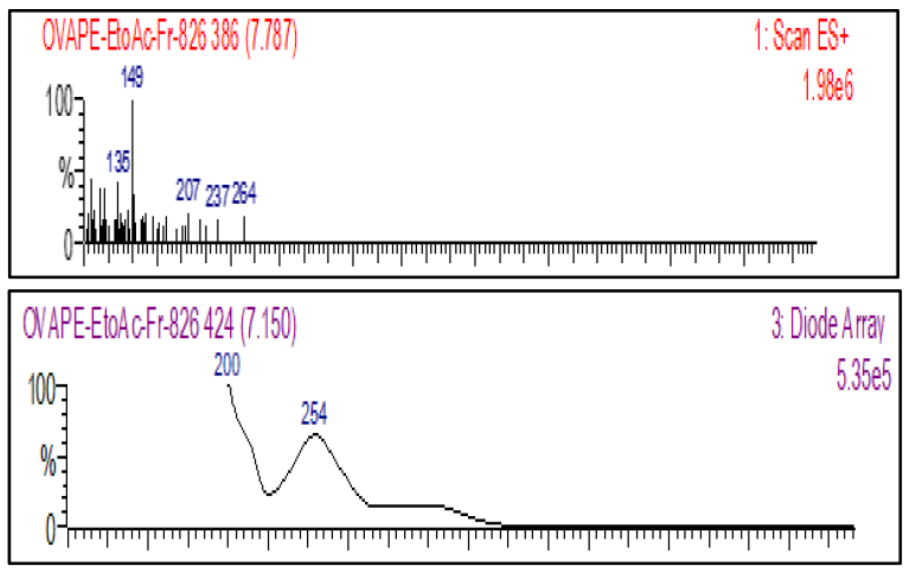

Figure 8: Mass and UV spectrum at the retention time 7.78.

identified can be isolated by various chromatographic techniques and can be further evaluated for various biological activities.

\section{CONCLUSION}

Origanum vulgare is a flavoring herb of the family Labiatae. The phytoconstituents present in the plant was the potential source for new drug and therapeuticleads. Phytochemical screening showed that the ethyl 
acetate extract of Origanum vulgare contains compounds either flavonoids or phenolic compounds. The LC-MS analysis has further brought light for the presence of phytosterols and bioflavonoid. The extract contained monoterpene hydrocarbons and phenolic compounds, the major ones being Chlorogenic acid, p-cymene and phytol. Taken together, these results reinforce the importance of this millennial species and open new perspectives for the research and design of new herbal medicines, obtained from indigenous vegetal material.

\section{ACKNOWLEDGEMENT}

The authors highly appreciate the University of Kashmir for providing necessary facilities.

\section{CONFLICT OF INTEREST}

The authors declare that they have no conflict of interest.

\section{ABBREVIATIONS}

LC-MS: Liquid Chromatography-Mass Spectrometry; SDBS: Spectral Data Base, MS: Mass Spectrometry; Q-TOF: Quadrupole-Time of Flight; DMSO: Dimethyl Sulfoxide; HPLC: High-Performance Liquid Chromatography.

\section{REFERENCES}

1. Durmowicz AG, Stenmark KR. Mechanisms of structural remodeling in chronic pulmonary hypertension. Pediatr Rev. 1999;20(11):91-102.

2. ArifT, Bhosale JD, Kumar N, MandalTK, Bendre RS, Lavekar GS, et al. Antifungal agents derived from plants. J Asian Nat Prod Res. 2009;11(7):621-38.

3. Tiwary BK, Bihani S, Kumar A, Chakraborty R, Ghosh R. The in vitro cytotoxic activity of ethnopharmacological important plants of Darjeeling district of West Bengal against different human cancer cell lines. BMC Comp and Alter Med. 2015;15(1):22.

4. Tiwari S. Plants: A rich source of herbal medicine. J Nat Products. 2008;1 (0):27-35.

5. Pignatti S, Guarino R, LaRosa M. Flora of Italy, $2^{\text {nd }}$ edition, Edagricole Milan. 2017.

6. Rios JL, Recio MC, Escandell JM, Andujar I. Inhibition of transcription factors by plant-derived compounds and their implications in inflammation and cancer. Curr Pharm Des. 2009;15(11):1212-37.

7. Gunawardena D, Shanmugam K, Low M, Bennett L, Govindaraghavan S, Head $R$, et al. Determination of anti-inflammatory activities of standardized preparations of plant-and mushroom-based foods. Eur J of Nutr. 2014;53(1):335-43.

8. Sahin F, Güllüce $M$, Daferera $D$, Sökmen A, Sökmen M, Polissiou M, et al. Biological activities of the essential oils and methanol extract of Origanum vulgare. Food control. 2004;15(7):549-57.

9. Sommavilla V, Haidacher-Gasser D, Sgarbossa M, Zidorn C. Seasonal variation in phenolics in leaves of Celtis australis. Bioch System Eco. 2012;41:110-4.

10. Licina BZ, Stefanovic OD, Vasic SM, Radojevic ID, Dekic MS, Comic LR. Biological activities of the extracts from wild growing Origanum vulgare L. Food Control. 2013;33(2):498-504

11. Rat MM, Gavaric NS, Kladar NV, Andric AM, Anackov GT, Bozin BN. The phenolics of the Ornithogalu mumbellatum L. Chemistry and Biodiversity. 2016;13(11):1551-8.

12. Bennaoum Z, Benhassaini $H$, Falconieri D, Piras A, Porcedda S. Chemica variability in essential oils from Ruta species. N product res. $2017 ; 31$ (19):2329-34.

13. Wagner $\mathrm{H}$, Bladt S. Plant drug analysis. $2^{\text {nd }}$ edition. Springer Science. 1996.

14. Hostettmann K, Wolfender JL, Terreaux C. Modern screening techniques for plant extracts. P Biology. 2001;39(sup1):18-32

15. Mellon FA, Bennett RN, Holst B, Williamson G. Intact glucosinolate analysis in plant extracts by programmed cone voltage electrospray LC/MS. A Biochem. 2002;306(1):83-91.

Article History: Submission Date : 06-01-2020; Revised Date : 18-02-2020; Acceptance Date : 14-04-2020.

Cite this article: Mir RH, Masoodi MH. Phytochemical Screening and Liquid Chromatography-Mass Spectrometry Studies of Ethyl Acetate Extract of Origanum vulgare. Int. J. Pharm. Investigation. 2020;10(2):132-5. 